\title{
Continuous processing of skim milk by a combination of pulsed electric fields and conventional heat treatments: does a synergetic effect on microbial inactivation exist?
}

\author{
Juliane FLOURY*, Noël GROSSET, Elodie LESNE, Romain JEANTET \\ UMR 1253, Science et Technologie du Lait et de l'Euf, Inra-Agrocampus Rennes, \\ 65 rue de Saint-Brieuc, 35042 Rennes Cedex, France
}

Received 4 July 2005 - Accepted 30 November 2005

\begin{abstract}
The objective of this research was to evaluate the effect of the combination of PEF with conventional heat treatment on the microbial inactivation of Salmonella enteritidis in skim milk. The purpose was to identify possible synergies that would make it possible to design minimal treatment regimes. Heat-resistance parameters $\left(D_{\theta}\right.$ and $\left.z\right)$ were firstly determined using a temperaturecontrolled water bath. Then, the effect of the PEF treatment followed by a heat treatment on the inactivation of Salmonella enteritidis in skim milk was evaluated using a PEF of $47 \mathrm{kV} \cdot \mathrm{cm}^{-1}$ / $500 \mathrm{~ns} / 60 \mathrm{~Hz}$, and a temperature of $62{ }^{\circ} \mathrm{C}$ for $19 \mathrm{~s}$, at a volumetric flow rate of $5 \mathrm{~L} \cdot \mathrm{h}^{-1}$. The effect of PEF or heating only was also studied with the same equipment. From the heat-resistance parameters previously determined, continuous heat processing at $62{ }^{\circ} \mathrm{C}$ for $19 \mathrm{~s}$ should give an inactivation ratio of $1.7 \mathrm{log}$. PEF processing of the milk resulted in a decimal reduction of $1.2 \pm 0.3 \log$ and the combination of the two operations gave a reduction of Salmonella enteritidis equal to $2.3 \pm$ $0.4 \mathrm{log}$. The results suggested that the combination of PEF and heating was more effective than each on its own. However, the lethality of the two treatments was additive rather than synergistic.
\end{abstract}

milk stabilization / Salmonella enteritidis / pulsed electric fields / heat treatment

摘要 - 脉冲电场和常规热处理结合连续处理脱脂乳对细菌灭活是否具有协同作用的研究。 本研究的主要目的是评价脉冲电场 (PEF) 和常规热处理结合使用时对脱脂乳中肠炎沙门氏 菌 (Salmonella enteritidis) 的作用效果。研究这两种处理方式是否具有协同作用, 并以此设 计最为经济合理的处理方法。首先要利用水浴控制温度来确定热抗参数 $\left(\mathrm{D}_{\theta}\right.$ 和 $\left.\mathrm{z}\right)$ 。然后, 评价 PEF 处理和热处理结合使用对脱脂乳中肠炎沙门氏菌的灭活效果, 试验条件为脱脂乳 以 $5 \mathrm{~L} \cdot \mathrm{h}^{-1}$ 的速度通过 PEF, 脉宽为 $500 \mathrm{~ns}$, 电场强度为 $47 \mathrm{kV} \cdot \mathrm{cm}^{-1}$, 脉冲频率为 $60 \mathrm{~Hz}$, 脱脂 乳在 $62{ }^{\circ} \mathrm{C}$ 下处理 $19 \mathrm{~s}$ 。在同一测试条件下也分别研究了 $\mathrm{PEF}$ 或加热对脱脂乳中肠炎沙门 氏菌的作用。根据试验确定的热抗参数, 在 $62{ }^{\circ} \mathrm{C}$ 连续热处理 $19 \mathrm{~s}$ 对肠炎沙门氏菌的灭活比 率 $\left(\log \mathrm{N}_{0} / \mathrm{N}\right)$ 为 $1.7 \log$ 。单独使用 PEF 处理脱脂乳, 肠炎沙门氏菌灭活比率为 $1.2 \pm 0.3 \log$, 而两种处理方式结合使用后可以使脱脂乳中肠炎沙门氏菌的灭活比率为 $2.3 \pm 0.4 \log$ 。试验 结果表明, PEF 和加热结合使用要比每一种方法单独使用时对细菌的灭活效果好。但是, 两种处理方式的对细菌的致死率是叠加作用, 而不是协同作用。

\section{牛乳稳定性 / 肠炎沙门氏菌 / 脉冲电场 / 热处理}

\footnotetext{
* Corresponding author (通讯作者): juliane.floury@ agrocampus-rennes.fr
} 
Résumé - Stabilisation de lait écrémé par champs électriques pulsés couplés à un traitement thermique classique : existe-t-il de réelles synergies entre ces deux opérations unitaires sur l'efficacité de l'inactivation microbienne ? L'objectif de cette étude était de déterminer si des synergies existent entre les CEP et les traitements thermiques en matière d'inactivation de Salmonella enteritidis dans le lait écrémé, et ainsi proposer des traitements de stabilisation correspondant au concept de traitement minimum. Les paramètres de résistance thermique $\left(\mathrm{D}_{\theta}\right.$ et $\left.\mathrm{z}\right)$ du microorganisme d'étude ont d'abord été caractérisés par traitements thermiques du lait écrémé en cuve thermostatée. Puis, l'effet d'un traitement par CEP à $47 \mathrm{kV} . \mathrm{cm}^{-1} / 500 \mathrm{~ns} / 60 \mathrm{~Hz}$ suivi d'un traitement thermique à $62{ }^{\circ} \mathrm{C}$ pendant $19 \mathrm{~s}$ a été évalué en continu à un débit volumique de $5 \mathrm{~L} \cdot \mathrm{h}^{-1}$. L'effet des CEP seuls ou d'un traitement thermique seul a été également évalué dans le même équipement. D'après les paramètres de résistance thermique, le traitement thermique du lait écrémé à $62^{\circ} \mathrm{C}$ pendant $19 \mathrm{~s}$ doit entraîner une destruction de $1.7 \log$. Le traitement par CEP seul a permis l'obtention d'un taux d'inactivation de $1.2 \pm 0.3 \mathrm{log}$, et le couplage des deux opérations unitaires a entraîné une réduction de Salmonella enteritidis de 2.3 $\pm 0.4 \mathrm{log}$. Le couplage des CEP à un traitement thermique modéré est donc plus efficace qu'un traitement par CEP seul ou qu'un traitement thermique classique. Cependant, nous pouvons seulement conclure à un effet létal d'ordre cumulatif de la mise en cascade des deux opérations unitaires plutôt qu'à un effet synergique.

stabilisation du lait / Salmonella enteritidis / champ électrique pulsé / traitement thermique

\section{INTRODUCTION}

The increasing demand for "fresh" and nutritious food products has raised the concern of the food industry for the development of milder preservation technologies to supplement existing pasteurization methods. In the food industry, thermal processes are widely used to achieve pasteurization and sterilization requirements. These thermal treatments are effective at reducing the number of pathogenic and spoilage bacteria, but they also have undesirable effects on the nutritional and organoleptic quality of food products.

Pulsed electric fields (PEF) technology has been extensively studied as a non-thermal preservation method used to inactivate undesirable microorganisms in liquid food products without the need for a high temperature that may modify their nutritional and sensory characteristics [1]. This preservation method is considered a non-thermal method because it has been demonstrated that microbial inactivation is mainly caused by the electric field, apart from the influence of other factors such as temperature [12].

Application of PEF delivers high-voltage pulses to a product placed between two conductive electrodes within a treatment chamber. It is coupled with a temperature increase caused by electric current flowing through the treated product [15]. The inten- sity of the electric current, and therefore the temperature increase, varies depending on the electrical characteristics of the treated product and equipment used [4].

Concerning the effect of the temperature on microbial inactivation effectiveness, numerous authors have observed that increasing the inlet temperature (from 22 to $50{ }^{\circ} \mathrm{C}$ ) increased the sensitivity of microorganisms to PEF treatment $[2,11,14]$. It was probably due to a synergy between the PEF and thermal effect. Some authors even recommend that PEF should be used together with moderate temperatures, i.e. approximately $45-55^{\circ} \mathrm{C}$ as a preservation method [5] to increase the killing effect. Hence, the temperature may play an important secondary role in microbial inactivation. It is known that the destruction of microorganisms by heating is based on a thermally-induced change in the original colloid-chemical structure of the cell protein [9]. This change leads either directly or indirectly to the inability of the cell to reproduce. However, the mechanisms behind the enhancement of bacterial inactivation by combining PEF and mild temperatures have not been determined yet. Several assumptions have been made [15]. Examples of such assumptions are: the reduction of the charging time of bacterial membranes due to increased electrical conductivity of the media caused by higher temperatures [13], changes in the phase state of cell membranes [6], and 
reduced trans-membrane breakdown potentials $[8,16]$.

In a previous study [3], the effectiveness of continuous PEF equipment (square wave pulses) on the total aerobic flora of raw skim milk and on Salmonella enteritidis inactivation under moderate temperatures $\left(\theta<50{ }^{\circ} \mathrm{C}\right)$ was evaluated. The results showed that the effectiveness of PEF processing on microbial inactivation was very limited: $1.4 \mathrm{log}$ reduction of total microflora and Salmonella enteritidis was the maximal inactivation obtained. Our objective here is to study the effectiveness on Salmonella enteritidis inactivation in skim milk of coupling PEF and conventional heat treatments, in order to identify potential synergies.

\section{MATERIALS AND METHODS}

\subsection{Bacterial culture and inoculation of skim milk}

The Salmonella enteritidis strain used in this study was a wild-type strain isolated from egg white (9066.94; Agence Francaise de Sécurité Sanitaire des Aliments, Paris, France) and conserved in cryobeads (AES Company, Combourg, France) at $-18{ }^{\circ} \mathrm{C}$. Before use, this strain was thawed and cultivated twice at $37{ }^{\circ} \mathrm{C}$ for $24 \mathrm{~h}$ in Tryptic Soy Broth (TSB, Biomerieux, Marcy l'Étoile, France). Stationary phase cells were collected and washed with glucose and sodium sulfate model solution (centrifugation $5000 \times g$ for $10 \mathrm{~min}$ at $20^{\circ} \mathrm{C}$, three times), and then inoculated at $2 \% \mathrm{v} / \mathrm{v}$ into the skim milk in order to obtain a final inoculum of about $10^{7}$ Salmonella enteritidis cells $\cdot \mathrm{mL}^{-1}$. The sterile UHT skim milk was purchased from a local grocery store (Leclerc, Cleunay, France). The milk composition was : $0.5 \mathrm{~g} \cdot \mathrm{kg}^{-1}$ of fat, $34.9 \mathrm{~g} \cdot \mathrm{kg}^{-1}$ of proteins, $48.5 \mathrm{~g} \cdot \mathrm{kg}^{-1}$ of lactose and $93.0 \mathrm{~g} \cdot \mathrm{kg}^{-1}$ of total solid, and the $\mathrm{pH}$ was 6.5. The electrical conductivity $\sigma\left(\mu S \cdot \mathrm{cm}^{-1}\right)$ of the skim milk as a function of the temperature was measured with a $145 \mathrm{~A}+$ conductivity meter (Orion, Cambridge, USA). For the temperature range between 0 and $65{ }^{\circ} \mathrm{C}$ the electrical conductivity followed a linear relation: $\sigma\left(\mu \mathrm{S} \cdot \mathrm{cm}^{-1}\right)=2097+82 \theta$ $\left({ }^{\circ} \mathrm{C}\right)$ with a $R^{2}$ value of 0.999 .

\subsection{Determination of heat-resistance parameters $\left(D_{\theta}\right.$ and $\left.z\right)$ of Salmonella enteritidis in skim milk}

\subsubsection{Thermobacteriology}

The kinetics of the bacterial population decrease versus time at a constant temperature $\theta$ is described by the following model:

$$
\mathrm{N}=\mathrm{N}_{0} 10^{-\left(\mathrm{t} / \mathrm{D}_{\theta}\right)}
$$

where $\mathrm{N}$ is the number of viable organisms per gram, $\mathrm{N}_{0}$ is the initial number of living organisms, $t$ is the exposure time (s) and $D_{\theta}$ the decimal reduction time (s). It is the time required to reduce the number of living organisms by a factor of 10 at the given temperature $\theta$. The $D_{\theta}$-value is a specific parameter of the thermal resistance of an organism.

The relation between $D_{\theta}$ and the temperature is described by equation (2):

$$
\log \frac{D_{\theta 1}}{D_{\theta 2}}=\frac{\theta_{2}-\theta_{1}}{z}
$$

where $\mathrm{z}$ is the increase in temperature necessary to increase the lethality of the heat treatment by a factor of 10 .

The two parameters $D_{\theta}$ and $z$ are dependent on the nature of the organism, its previous history and the nature of the medium. The determination method can also have some minor effect.

\subsubsection{Thermal treatment of milk}

$\mathrm{D}_{\theta}$-values in skim milk were determined at five different temperatures : $56,57.5,59$, 61 and $62{ }^{\circ} \mathrm{C}$. The $\mathrm{z}$-value was deducted from previous $D_{\theta}$-values.

Capillary tubes (230 mm Pipette Pasteur, Grosseron, Saint-Herblain, France) were filled with $100 \mu \mathrm{L}$ of sample and the ends were sealed with a flame. The tubes were submitted to thermal treatments in a temperature-controlled water bath. After heating, the tubes were cooled in iced water before being broken and their contents poured into an Eppendorf tube for enumeration of cells. 


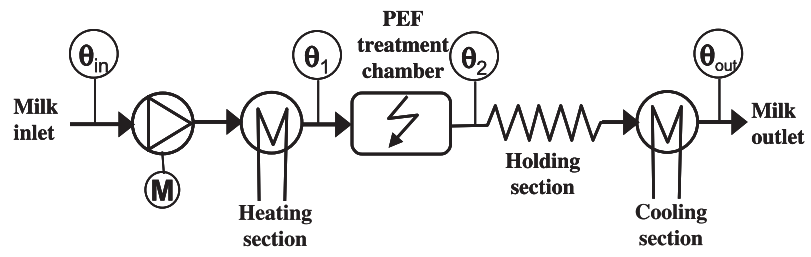

Figure 1. Flow chart of the pilot-plant combining PEF and conventional heat treatment.

The temperature of the bath was precisely measured $\left( \pm 0.15^{\circ} \mathrm{C}\right)$ with a standard thermometer $\left(\mathrm{n}^{\circ} 02050070,-1\right.$ to $101{ }^{\circ} \mathrm{C}$, Alla France, Chemillé, France) and experiments were done in triplicate for each temperature.

\subsubsection{Bacteriological analysis}

Each study was conducted in triplicate using independently prepared batches of milk and fresh bacteria for every replicate. Salmonella enumeration was carried out on the inoculated skim milk before and after each test. Serial decimal dilutions in tryptone $\left(1 \mathrm{~g} \cdot \mathrm{L}^{-1}\right)$-salt $\left(8.5 \mathrm{~g} \cdot \mathrm{L}^{-1}\right)$ water $(\mathrm{TS}$, AES, Combourg, France) were prepared, and a 1-mL sample of each dilution was plated out in Tryptic Soy Agar (TSA, Biomerieux, Marcy l'Étoile, France). After incubation at $37^{\circ} \mathrm{C}$ for $24 \mathrm{~h}$, the colonyforming units (CFU) were counted.

\subsubsection{Data analysis}

$\mathrm{D}_{\theta}$-values were determined from the straight portion of the $\log \mathrm{N}$ against time curves. The parameters of the models were estimated with a linear regression method carried out with Excel software.

2.3. Combination of PEF and conventional heat treatments on inactivation effectiveness of Salmonella enteritidis in skim milk

\subsubsection{Experimental setup}

The experimental setup, shown in Figure 1, consists of a 5-L supply tank, a variable speed pump (Micropump, IDEX Corporation, Vancouver, USA), a tubular heat exchanger, a PEF treatment chamber, a holding section and a cooling system.

The continuous PEF equipment (Fig. 2; Europulse, Cressensac, France) uses an original pressurized spark gap switching technology (dry air) with a high repetition rate, connected to a pulse-forming line consisting of a coaxial cable and lumped elements. This equipment, including a $2-\mathrm{kW}$ high voltage power supply charging capacitors and an interactive computer control (Labview software), generates square waveform pulses. It is designed to allow a widely adjustable operating pulse width (from 50 up to $3000 \mathrm{~ns}$ ), electric field strength (from 30 up to $80 \mathrm{kV} \cdot \mathrm{cm}^{-1}$ ), pulse frequency (from 1 up to $815 \mathrm{~Hz}$ ) and volumetric flow rate (from 1 up to $10 \mathrm{~L} \cdot \mathrm{h}^{-1}$ ). The coaxial continuous PEF treatment chamber (Fig. 2) consists of two electrodes separated by a gap of $2 \mathrm{~mm}$. The treatment chamber is equipped with a high voltage resistive and a current monitor for the direct measurement of applied voltage and current with a TDS 3012 digital oscilloscope (Tektronix, Beaverton, USA). The temperature rise due to ohmic heating in the PEF treatment chamber is measured with two thermocouples placed immediately before and after the chamber.

The holding section consists of a silicone tube (6.4 mm inner diameter, $1.72 \mathrm{~m}$ length) immersed in a temperature-controlled water bath to avoid heat loss.

The heating and the cooling sections of the heat exchanger are made of stainless tubes (8 $\mathrm{mm}$ inner diameter, $2 \mathrm{~m}$ length) immersed in water baths at a controlled temperature. 


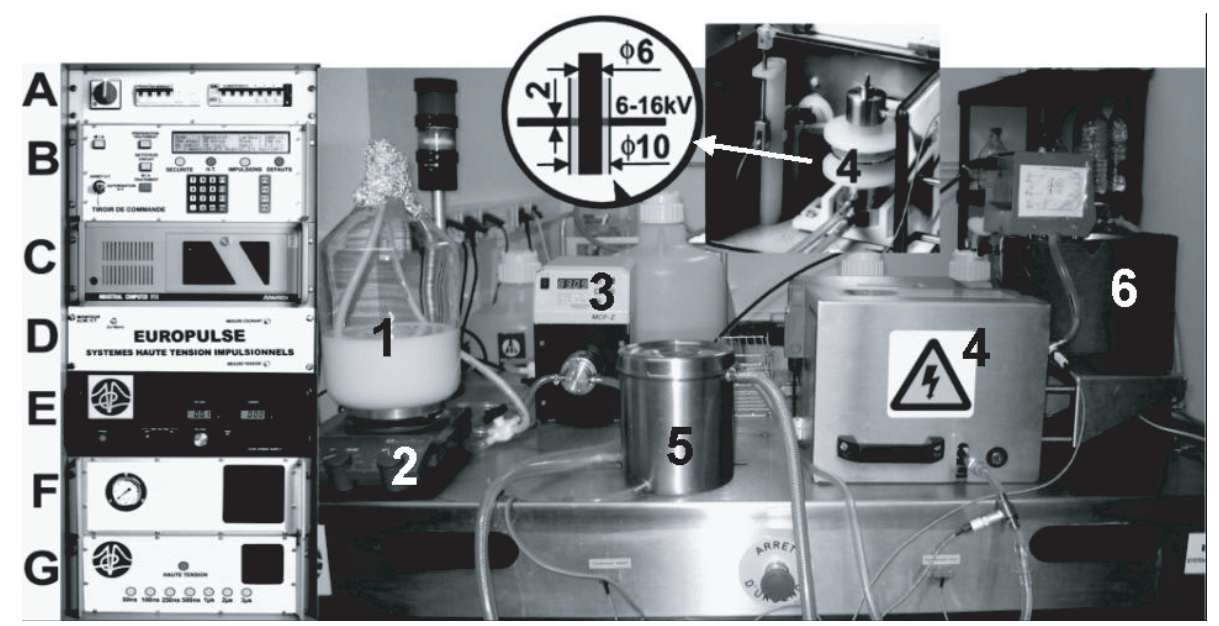

Figure 2. Equipment for continuous PEF treatment of liquid products.

Control panel: A: power supply; B: programing and control unit; $\mathrm{C}$ : computer, D and E: high voltage monitor and power supply $(50 \mathrm{kV}, 2 \mathrm{~kW}) ; \mathrm{F}=\operatorname{spark}$ gap switch $(0-815 \mathrm{~Hz})$; G: high voltage energy storage (50 ns, $100 \mathrm{~ns}, 250 \mathrm{~ns}, 500 \mathrm{~ns}, 1 \mu \mathrm{s}, 2 \mu \mathrm{s}, 3 \mu \mathrm{s}$ ).

Hydraulic line: 1: supply tank (5 L); 2: magnetic stirrer; 3: speed pump; 4: PEF treatment chamber; 5: tubular heat exchanger; 6 : temperature-controlled water bath for holding section.

Their position in the circuit can be modified according to the experimental application considered: PEF treatment alone, PEF + heat treatment or heat treatment only.

A septum was placed at the exit of the cooling heat exchanger to allow approximately $2 \mathrm{~mL}$ of treated milk to be taken with a $10-\mathrm{mL}$ sterile syringe. Three different samples were taken for each experiment, at one-minute intervals to test the reproducibility of the treatment. At the same moment, the temperatures were also recorded.

\subsubsection{Experimental process parameters}

Experiments were carried out at a volumetric flow rate of $5 \mathrm{~L} \cdot \mathrm{h}^{-1}$. Milk was preheated in the first heat exchanger section to the temperature $\theta_{1}=42^{\circ} \mathrm{C}$. Then PEF treatment of the milk was performed at $47 \mathrm{kV} \cdot \mathrm{cm}^{-1}, 500 \mathrm{~ns}$ and $60 \mathrm{~Hz}$, producing a quasi-instantaneous temperature rise of $20{ }^{\circ} \mathrm{C}$. At the temperature $\theta_{2}=62{ }^{\circ} \mathrm{C}$, the milk was held for $38 \mathrm{~s}$ and then cooled down to the temperature $\theta_{\text {out }}$ before being sampled (Fig. 3).

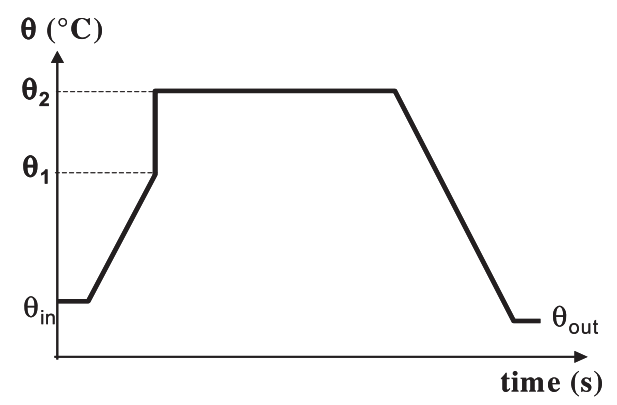

Figure 3. Temperature evolution of the skim milk during combined PEF and heat treatments.

Three other experimental devices were set up, in order to study possible synergies between the coupled PEF and thermal treatments:

- The second experimental setup allowed us to determine the effect of PEF treatment alone. The holding section was removed and the PEF chamber connected to the cooling section. As previously, the milk was preheated to $42{ }^{\circ} \mathrm{C}$ 
before PEF treatment, causing a $20{ }^{\circ} \mathrm{C}$ temperature rise. Finally, the milk was cooled down before being sampled.

- The third experimental device was for the continuous heat treatment of milk. The objective was to study the effect of thermal treatment alone on Salmonella enteritidis inactivation. The milk was preheated to $\theta^{\prime}{ }_{1}=59{ }^{\circ} \mathrm{C}$ and held for $38 \mathrm{~s}$. This lower heat-treatment temperature $\left(59^{\circ} \mathrm{C}\right)$ was preferred to $62{ }^{\circ} \mathrm{C}$ in order to limit the microbial destruction that takes place during the slow temperature increase in the heat exchanger and the slow temperature decrease in the cooling section.

- Finally, the inactivation ratio achieved during the flow of the milk through the heating section from $\theta_{\text {in }}$ to $59{ }^{\circ} \mathrm{C}$ and cooling section from $59{ }^{\circ} \mathrm{C}$ to $\theta_{\text {out }}$ was also determined thanks to a fourth experimental device in order to deduce the effect of the holding section alone.

\subsubsection{Flow regime}

The flow regime in the PEF chamber was previously determined by Jeantet et al. [7], who established the relation between the Darcy (Da) and Reynolds (Re) numbers for water at $20^{\circ} \mathrm{C}$. They showed that for circulating volumetric flows ranging between 1 and $10 \mathrm{~L} \cdot \mathrm{h}^{-1}$, the Reynolds number varied between 20 and 220 and that the critical Re value, marking the transition between laminar flow and turbulent, was 310 . In our experiments, skim milk was circulating in the equipment at $5 \mathrm{~L} \cdot \mathrm{h}^{-1}$. The flow regime was therefore fully laminar. In the tubular holding section, the Reynolds number was 280 . This value being much lower than the critical Re of 2000 for a cylindrical geometry, the regime was also laminar in the heat-treatment zone.

Classically, heat processing of liquids through heat exchangers might be carried out under turbulent flow conditions to limit deposits on the walls of the exchangers and to give a uniform time-temperature treatment. Under the laminar flow regime, the velocity profile is not uniform and all microorganisms might not undergo the same selected time-temperature regime during the process since the residence time is variable.

However, the choice to use laminar flow at $5 \mathrm{~L} \cdot \mathrm{h}^{-1}$ was deliberate when the Europulse equipment was developed (Program AQS 99P0631), in order to be able to apply the Poiseuille equation for the flow profile. This allows us to calculate the maximum velocity of the fluid $\left(\mathrm{v}_{\max }\right)$ in the holding section according to equation (3) :

$$
\overline{\mathrm{v}}=\frac{\dot{\mathrm{V}}}{\pi \cdot \mathrm{R}^{2}}=\frac{\Delta \mathrm{P}}{8 \eta \mathrm{L}} \mathrm{R}^{2}=\frac{\mathrm{v}_{\max }}{2}
$$

with $\dot{\mathrm{V}}$ : volumetric flow of the treated fluid $\left(\mathrm{m}^{3} \cdot \mathrm{s}^{-1}\right)$, L: length and $\mathrm{R}$ : radius of the holding section $(\mathrm{m})$.

The destruction of microorganisms being a non-linear reaction which has to be carried out close to its term, one would expect the inactivation ratio obtained experimentally to correspond to that of the fastest fraction, circulating at a speed equal to $\mathrm{v}_{\max }$.

\subsubsection{Data analysis}

Microbial data were analyzed using the statistical analysis package Statgraphics Plus, version 5.1. Student's $t$ statistic tests were used to determine if the averages of two sets of measurements were significantly different. In all cases, a $P$-value $<0.05$ was considered significant.

\section{RESULTS AND DISCUSSION}

\subsection{Heat-resistance parameters}

The whole set of data obtained after the heat treatments of the inoculated skim milk is summarized in Table I. Decimal reduction times $D_{\theta}$ were determined by plotting the logarithm of the inactivation ratio $\left(\mathrm{N}_{0} / \mathrm{N}\right)$ vs. heating time. The standard deviations were probably due to uncertainties in the bacterial enumeration method which has a possible error of $\pm 0.5 \log 10$, or to variations in the resistance to stress of the microbial strain. 
Table I. $\mathrm{D}_{\theta}$ values obtained at 5 different temperature treatments of Salmonella enteritidis in skim milk.

\begin{tabular}{lccccc}
\hline & \multicolumn{5}{c}{$\theta\left({ }^{\circ} \mathrm{C}\right)$} \\
\cline { 2 - 6 } Test No & $56.2 \pm 0.15$ & $57.5 \pm 0.15$ & $59.2 \pm 0.15$ & $61.0 \pm 0.15$ & $62.3 \pm 0.15$ \\
\cline { 2 - 6 } & 161 & 107 & 36 & 22 & 10 \\
\hline 1 & 175 & - & 30 & - & 12 \\
2 & 167 & - & 50 & - & 18 \\
3 & 168 & 107 & 39 & 22 & 13 \\
Average & 7 & - & 10 & - & 4 \\
\hline Standard deviation & 7 & & & & \\
\hline
\end{tabular}

Decimal reduction time curves were obtained by plotting $\log \mathrm{D}_{\theta}$ vs. treatment temperatures. The heat-resistance parameter $\mathrm{z}$ was deduced from the inverse of the slope, as shown in equation (2). The following general equation was developed to calculate the $\mathrm{D}_{\theta}$-value of Salmonella enteritidis heated at any temperature $(\theta)\left(R^{2}=0.99\right)$ within the range used in this investigation:

$$
\log \mathrm{D}_{\theta}=12.5-(1 / \mathrm{z}) \theta
$$

where the z-value was equal to $5.4{ }^{\circ} \mathrm{C}$. This value matches z-values referred to in the literature for Salmonella enteritidis, usually between 4 and $5.5^{\circ} \mathrm{C}$ [10].

\subsection{Coupled PEF - thermal treatment process}

\subsubsection{Heat-treatment time}

If the microbial inactivation ratio actually corresponds to the fastest fraction circulating at $\mathrm{v}_{\max }$, then it was possible, knowing the dimensions of the holding section and the volumetric flow, to calculate from equation (3) the theoretical heat-treatment time applied to the bacterial population of the skim milk flowing from the PEF cell:

$$
\mathrm{t}=\mathrm{L} / \mathrm{v}_{\max }=19 \mathrm{~s} \text {. }
$$

Knowing the heat-resistance parameters $\mathrm{D}_{\theta}$ and $\mathrm{z}$ of Salmonella enteritidis in skim milk, the validity of the previous assumption was checked using the continuous heatprocessing experimental device. According to equation (4), at the temperature of $59{ }^{\circ} \mathrm{C}$ chosen for the continuous heat treatment, the decimal reduction time $\mathrm{D}_{\theta}$ was equal to $38 \mathrm{~s}$, whereas it was equal to $11 \mathrm{~s}$ at $62{ }^{\circ} \mathrm{C}$. The inactivation ratio obtained during the flow of the milk in the heating and the cooling sections was also determined. The effect of the holding section alone was then found by deducting the effect of the heating and cooling sections. The results of the various tests are recapitulated in Table II.

Considering that in the holding section the experimental inactivation ratio should correspond to the theoretical heat-treatment time, we should obtain:

$\log \mathrm{N}_{0} / \mathrm{N}=\mathrm{t} / \mathrm{D}_{59}=19 / 38=0.5$ decimal reductions.

Experimentally, the average inactivation ratio corresponding to the heating at $59{ }^{\circ} \mathrm{C}$ in the holding section at a volumetric flow of $5 \mathrm{~L} \cdot \mathrm{h}^{-1}$ was also equal to $0.5 \pm 0.2 \mathrm{dec}$ imal reductions (Tab. II). It could be concluded that the assumption made to calculate the theoretical heat-treatment time was valid and that the processing time to consider for the heat treatment of the milk in the equipment was equal to 19 seconds.

It was then possible to estimate the inactivation ratio obtained after a heating at $62{ }^{\circ} \mathrm{C}$. With a decimal reduction time $\mathrm{D}_{62}$ of $11 \mathrm{~s}$, according to equation (1), $\log \mathrm{N}_{0} / \mathrm{N}$ is $19 / 11=1.7$. The share of the heat treatment only on the inactivation of Salmonella enteritidis should be about 1.7 decimal reductions during the global coupled processing of the milk. 
Table II. Inactivation ratios $\left(\log \mathrm{N}_{0} / \mathrm{N}\right)$ of Salmonella enteritidis in skim milk obtained after: continuous heat treatment (HT) at $59{ }^{\circ} \mathrm{C}$ with classical heating $(\mathrm{H})$ and cooling $(\mathrm{C})$ steps in heat exchangers, noted $(\mathrm{HT}+\mathrm{H}+\mathrm{C})_{59^{\circ} \mathrm{C}}$; slow heating $(\mathrm{H})$ and cooling $(\mathrm{C})$ of the milk in the two heat

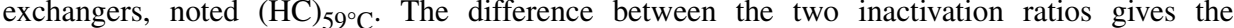
effectiveness of the heating treatment at $59{ }^{\circ} \mathrm{C}$ in the tubular chamber only, noted $(\mathrm{HT}) 59^{\circ} \mathrm{C}$.

\begin{tabular}{lccc}
\hline & \multicolumn{3}{c}{$\log \mathrm{N}_{0} / \mathrm{N}$} \\
\cline { 2 - 4 } Test No $^{\text {a }}$ & $(\mathrm{HT}+\mathrm{H}+\mathrm{C})_{59^{\circ} \mathrm{C}}$ & $(\mathrm{HC})_{59^{\circ} \mathrm{C}}$ & $(\mathrm{HT})_{59^{\circ} \mathrm{C}}=(\mathrm{HT}+\mathrm{H}+\mathrm{C})-(\mathrm{HC})$ \\
\hline 1 & $2.5 \pm 0.3$ & $1.2 \pm 0.2$ & $1.3^{\mathrm{b}}$ \\
2 & $1.8 \pm 0.2$ & $1.1 \pm 0.1$ & 0.7 \\
3 & $1.3 \pm 0.3$ & $0.9 \pm 0.2$ & 0.4 \\
\hline \multicolumn{3}{c}{ Average ratio of inactivation } & $0.5 \pm 0.2$ \\
\hline
\end{tabular}

a Each test number corresponds to experiments carried out on different dates.

b Statistically different value, not taken into account in the calculation of the average $\log \mathrm{N}_{0} / \mathrm{N}$.

Table III. Inactivation ratios of $S$. enteritidis obtained after (1) combined PEF and heat treatments at $62{ }^{\circ} \mathrm{C}$ and (2) PEF processing of the skim milk only.

\begin{tabular}{|c|c|c|c|}
\hline \multicolumn{2}{|c|}{ (1) } & \multicolumn{2}{|c|}{ (2) } \\
\hline Test No a & $\log \left(\mathrm{N}_{0} / \mathrm{N}\right)$ & Test No & $\log \left(\mathrm{N}_{0} / \mathrm{N}\right)$ \\
\hline 1 & $2.6 \pm 0.6$ & 1 & $1.6 \pm 0.9$ \\
\hline 2 & $2.0 \pm 0.5$ & 2 & $0.9 \pm 0.1$ \\
\hline 3 & $2.8 \pm 0.2$ & 3 & $1.2 \pm 0.1$ \\
\hline 4 & $1.7 \pm 0.3$ & 4 & $1.1 \pm 0.3$ \\
\hline 5 & $2.3 \pm 0.1$ & & \\
\hline Average & 2.3 & Average & 1.2 \\
\hline Standard deviation & 0.4 & Standard deviation & 0.3 \\
\hline
\end{tabular}

a Each test number corresponds to experiments carried out on different dates.

\subsubsection{Coupled PEF - thermal treatment process: is there a synergistic effect between the treatments?}

The inactivation ratios of Salmonella enteritidis obtained for the combination of $\mathrm{PEF}$ and heat treatments at $62^{\circ} \mathrm{C}$ and for the $\mathrm{PEF}$ processing only of the skim milk are reported in Table III. The average decimal reduction was $2.3 \pm 0.4$ for the coupled treatment. The average microbial inactivation ratio for the PEF treatment of the milk alone was equal to $1.2 \pm 0.3$. Results were quite variable between the tests, with values ranging between 1.7 and $2.8 \log$ of reduc- tion for the combined treatment. However, statistical analysis revealed that the two treatments were significantly different with a $P$-value $<5 \%$. The variability was most probably due to different responses to the various stresses applied to the microbial Salmonella enteritidis species.

It was concluded that the effectiveness of the thermal treatment at $62{ }^{\circ} \mathrm{C}$ on the inactivation of Salmonella enteritidis in skim milk was improved by combining it with a PEF treatment. However, there is not a significant synergistic lethal effect of the combined PEF-thermal treatment process on this bacteria. The benefit of the coupled treatment was cumulative rather than 
synergistic. Its effectiveness was quite simply equivalent to the setting in series of the two operation units: the PEF treatment deactivated first about $1 \log$ of the microbial population, then the thermal treatment at $62^{\circ} \mathrm{C}$ removed about $1.5 \log$ of it.

\section{CONCLUSION}

The effect of the coupled PEF-thermal treatment on the inactivation effectiveness of Salmonella enteritidis in skim milk was evaluated. As a comparison, a continuous PEF treatment and a heating treatment alone at the same volumetric flow rate were studied. Continuous heat processing of milk at $62{ }^{\circ} \mathrm{C}$ for $19 \mathrm{~s}$ should theoretically involve an inactivation ratio $\left(\log \mathrm{N}_{0} / \mathrm{N}\right)$ of $1.7 \mathrm{log}$; PEF processing of the milk allowed us to reach a decimal reduction of $1.2 \pm$ $0.3 \log$. The combination of the two operation units involved a reduction of Salmonella enteritidis of $2.3 \pm 0.4 \mathrm{log}$. The results suggested that the combination of PEF and heat treatments was more efficient than PEF or conventional heat treatment alone but it was not a synergistic effect.

This study provided the evidence that the cumulative effect of combining the PEF process with a conventional heating treatment exists. This result thus opens the way for alternative treatments to thermal pasteurization for stabilizing thermosensitive products, especially under milder conditions of temperature.

\section{REFERENCES}

[1] Barbosa-Canovas G., Gongora-Nieto M., Pothakamury U., Swanson B., Preservation of food with pulsed electric fields, Academic Press, San Diego, USA, 1999.

[2] Calderon-Miranda M.L., Barbosa-Canovas G.V., Swanson B.G., Inactivation of Listeria innocua in skim milk by pulsed electric fields and nisin, Int. J. Food Microbiol. 51 (1999) 19-30.

[3] Floury J., Grosset N., Leconte N., Pasco M., Madec M.-N., Jeantet R., Continuous raw skim milk processing by pulsed electric field at non lethal temperature: effect on microbial inactivation and functional properties, Lait 86 (2006) 43-57.
[4] Heinz V., Alvarez I., Angersbach A., Knorr D., Preservation of liquid foods by high intensity pulsed electric fields - basic concepts for process design, Trends Food Sci. Technol. 12 (2002) 103-111.

[5] Hulsheger H., Pottel J., Niemann E., Killing of bacteria with electric pulses of high fields strength, Rad. Env. Biophysics. 20 (1981) 53-65.

[6] Jayaram S., Castle G., Margaritis A., Effects of high electric fields pulses on Lactobacillus brevis at elevated temperatuires, IEEE Ind. Appl. Soc. 40 (1992) 1412-1420.

[7] Jeantet R., Carballeira Fernández J.A., Roignant M., Cochet M.F., Baron F., Korolczuk J., Brion J.C., Performances d'un nouvel appareil de décontamination microbienne de produits liquides en continu par champs électriques pulsés, Ind. Alim. Agric. 4 (2003) 9-14.

[8] Kinosita K., Tsong T., Voltage-induced pore formation and hemolysis of human erythrocytes, Bioch. Biophys. Acta 471 (1977) 227-242.

[9] Leniger H.A., Beverloo W.A., Food Process engineering, D. Reidel Publishing company, Dordrecht, Holland, 1975.

[10] Mañas P., Pagán R., Raso J., Condón S., Predicting thermal inactivation in media of different $\mathrm{pH}$ of Salmonella grown at different temperatures, Int. J. Food Microbiol. 87 (2003) 45-53.

[11] Reina L.D., Jin Z.T., Zhang Q.H., Yousef A.E., Inactivation of Listeria monocytogenes in milk by pulsed electric fields, J. Food Prot. 61 (1998) 1203-1206.

[12] Sale A., Hamilton W., Effect of high electric fields on microorganisms. I. Killing of bacteria and yeast, Biochem. Biophys. Acta 148 (1967) 781-788.

[13] Schwan H., Electrical properties of tissues and cell suspensions, Adv. Biol. Med. Phys. 5 (1957) 147-209.

[14] Sensoy I., Zhang Q.H., Sastry S.K., Inactivation kinetic of Salmonella dublin by pulsed electric fields, J. Food Proc. Eng. 20 (1997) 367-381.

[15] Sepulveda D.R., Gongora-Nieto M.M., SanMartin M.F., Barbosa-Canovas G.V., Influence of treatment temperature on the inactivation of Listeria innocua by pulsed electric fields, Lebensm.-Wiss. U.-Technol. 38 (2005) 167-172.

[16] Zimmermann U., Electrical breakdown, electropermeabilization and electrofusion, Rev. Physiol. Biochem. Pharmac. 105 (1986) 176-257. 